\title{
Implications of Applied P-Sources with Calcium Super Phosphate, Phosphoric Acid and Rock Phosphate, and Phosphate Dissolving Bacteria on Snap Bean Grown Under Greenhouses Conditions
}

\author{
M. E. Zaki' ${ }^{1}$ M. H.M. Mohamed ${ }^{1}$, Mona.M. Abd EL-wanis ${ }^{2}$, A.A.A. Glala ${ }^{3}$, A.H.M. Hamoda ${ }^{2}$, A. S. Shams ${ }^{1}$ \\ 1- Horticulture Department, Faculty of Agriculture, Benha University, Egypt. \\ 2- Horticulture Research institute Department, Agriculture Research Center (ARC). \\ 3- Department of Vegetable Res. National Research Center, Dokki, Giza, Egypt.
}

\begin{abstract}
Two field experiment were carried out during the two successive winter seasons of 2017-2018 and 2018-2019 in a private sector farm at Damallo Village, Qalubia Governorate, to investigate the effect of different sources of phosphorus as a soil application i.e., Calcium superphosphate $\left(15.5 \% \mathrm{P}_{2} \mathrm{O}_{5}\right)$ at $50 \mathrm{~g} / \mathrm{m}^{2}$, Rock phosphate $\left(26.3 \% \mathrm{P}_{2} \mathrm{O}_{5}\right)$ at $27 \mathrm{~g} / \mathrm{m}^{2}$, Phosphoric acid $\left(56 \% \mathrm{P}_{2} \mathrm{O}_{5}\right)$ at $14.3 \mathrm{mg} / \mathrm{m}^{2}$ at recommended dose with/ without bio fertilizer Bacillus megaterium var. phosphaticum "phosphate dissolving bacteria "PDB" as well as their interaction on vegetative growth, chemical composition and productivity as well as pod quality of snap bean (Phaseolus vulgaris L.) cv. moraleda. Results showed that using Phosphoric acid $\left(56 \% \mathrm{P}_{2} \mathrm{O}_{5}\right)$ fertilizer at the recommended dose of mineral fertilizer reflected significantly highest values in all measured vegetative growth aspects, chemical constituents of plant foliage, pod yield and its quality of bean plants compared with rock phosphate at the recommended dose of mineral fertilizer which gave the lowest values in the two seasons of study. In addition, fertilizing snap bean plants with Bio-Phosphorus fertilizer contained phosphate dissolving bacteria (PDB) (Bacillus megaterium var phosphaticum) at rate of $4 \mathrm{~L} /$ greenhouse applied alone at soil subsurface near the plant roots at two time started after two weeks from transplantation with one month interval at $21 / 360 \mathrm{~m}^{2}$ increased all measured parameters compared with the treatment without addition in the two seasons of study. Moreover, fertilizing the plants with different sources (p) plus (PDB) gave the highest values in most measure under study, fertilizing plants with phosphoric acid plus PDB gave the highest values in all vegetative growth aspects, fruit pod yield and the best quality compared with other treatments during both seasons of study.
\end{abstract}

Key words : Snap bean-Calcium super phosphate- Rock phosphate- Phosphoric acid- Phosphateen (Bacillus megaterium var. phosphaticum )- phosphate dissolving bacteria - PDB - bio- fertilizerVegetative growth-Yield- Pod quality- Green house.

\section{Introduction}

Snap bean (Phaseolus vulgaris L.) is one of the most important cash leguminous vegetable crops grown in Egypt for local consumption and exportation. Snap bean characterized by its high content of protein, starch, and dietary fiber and considered as an excellent source of potassium, molybdenum, selenium, thiamine B1, niacin B6, and folic acid (Maiti and Singh., 2007). In Egypt, snap bean production area was42108 fed produced 175,898 tons with an average yield of about 4.2 tons /fed. Cultivated area under greenhouse are 1196370 $\mathrm{m} 2$ (2586 greenhouses) and total production of 7914 tons with an average productivity of $6.615 \mathrm{~kg} / \mathrm{m} 2$. (Bulletin of the Agric. Statistics.2017Ministry of Agric. and land Reclamation, Economic Affairs Sector). Moreover, the quantity of exported pods in 2018 reached 23,761 tons, mostly to England, Belgium, Germany, Italy and the Netherlands (Central Administration of Agricultural Quarantine General Union of Producers and Exporters of Horticultural Crops).

Phosphorus (P) is one of the major plant nutrients which constitutes about $0.2 \%$ of plant dry weight (Schachtman et al., 1998). Phosphorus is considered as an integral part of the cellular activities of living organisms and contributes to several vital functions in the plant, such as early root and seedling growth, improving winter hardiness, promotion of early heading and uniform maturity, increasing seed formation and quality, and increasing water-use efficiency. Moreover, it is involved in several key plant functions including cell division, photosynthesis, storing and transfer of energy, regulation of some enzymes, transformation of sugars and nutrients within the plant, as well as, the transfer of genetic characteristics from one generation to another (Taiz et al., 2015). Phosphorus deficiency affects not only plant growth and development and crop yield, but also the quality of the fruit and the formation of seeds (Njira and Nabwami., 2015). Availability, absorption and effectiveness of phosphorus to plants depends on many factors like $\mathrm{pH}$, physicochemical properties of the soil, dominant climate and soil organic matter content and P fertilizer sources(Gupta et al. 1985 and Ghoname et al. 2012).

In Egypt, superphosphates and rock phosphate constitute the main sources of $\mathrm{P}$ fertilizers used for agricultural production for a long time but recently other alternatives became available such as phosphoric acid that usually used to produce $\mathrm{P}$ fertilizers which is a costly and energy consuming process. However, its direct use has been found effective when it was applied through irrigation water after the emergence of maize and wheat grown under alkaline and calcareous soil conditions. Half 
dose of $\mathrm{P}$ as phosphoric acid produced as much maize yield was produced by the full dose of $\mathrm{P}$ as single super phosphate "SSP"(Niab., 2002). Some Australian scientists also confirmed the superiority of fluid P fertilizers over the granular P-fertilizers and produced $31 \%$ more wheat yield (Holloway et al., 2001). Also, superphosphate was the first commercial mineral fertilizer, and it led to the development of the modern plant nutrient industry. This material was once the most commonly used fertilizer, but other phosphorus (P) fertilizers have largely replaced SSP because of its relatively low $\mathrm{P}$ content. are manufactured by reacting insoluble mineral phosphate with acid to create a soluble, readily available form of phosphate. Single super phosphate is about 20 percent phosphate.

Chemical fertilizers have several negative impacts on environment and sustainable agriculture. Therefore, bio fertilizers are recommended in these conditions and growth prompting bacteria have been used as a replacement of chemical fertilizers (Wu et al., 2005). The use of phosphate solubilizing bacteria as inoculants simultaneously increases $\mathrm{P}$ uptake by the plant and crop yield. Strains from the genera Pseudomonas, Bacillus and Rhizobium are the most powerful phosphate solubilizes (Rodríguez and Fraga., 1999). (Keneni et al.,2010)indicated that faba bean have a potential to form association with phosphate solubilizing bacteria.Potent PSB including Pseudomonas sp., Rhizobium sp. and Bacillus sp. are mainly solubilized phosphate pool by production of organic acid which is easily uptake by the plant. These microorganisms can play an important role in improving yield and its components, phosphate uptake efficiency and plant growth by releasing phosphorus from soil (Awasthi et al., 2011) .

Rock phosphate (RP) is one of the indigenous phosphate sources in many countries. The phosphorus content in the rock ranged from 25 to 31 $\%$ P2O5with low solubility (Adetunji., 2005).
Application of rock phosphate has been proved to be beneficial to plant growth and productivity (Akande et al., 2008). The methods of enhancing the quality of rock phosphate and its agronomic efficiency included composting RP.

Current study aimed to determine the effect different sources of phosphorus such as a soil application i.e., Calcium superphosphate, Rock phosphate and Phosphoric acid (with or without bio fertilizer Bacillus megaterium var. phosphaticum "phosphate dissolving bacteria "PDB" as well as their interaction on vegetative growth, chemical composition and productivity as well as pod quality of snap bean

\section{Materials and Methods.}

Two field experiments were carried out during the two winter successive seasons of 2017-2018 and 2018-2019 in private sector farm at Damallo Village, Benha, Qalubia Governorate to investigate the effect of different sources of phosphorus as a soil application i.e., Calcium super phosphate $(15.5 \%$ $\mathrm{P} 2 \mathrm{O} 5)$ at $50 \mathrm{~g} / \mathrm{m} 2$, Rock phosphate $(26.3 \%$ P2O5) at $27 \mathrm{~g} / \mathrm{m} 2$, Phosphoric acid (56\%P2O5) at $14.3 \mathrm{mg} / \mathrm{m} 2$ at recommended dose with/ without bio fertilizer Bacillus megaterium var. phosphaticum "phosphate dissolving bacteria "PDB" as well as their interaction on vegetative growth, chemical composition and productivity as well as pod quality of snap bean (Phaseolus vulgaris L.) cv. Moraleda grown under greenhouses conditions $(18 * 18 * 3.5$ meter). Soil samples were taken at $30 \mathrm{~cm}$ from soil surface and soil physical and chemical properties were determined according to Jackson (1973) and Black (1982) and were illustrated at Table (1). Moreover, maximum and minimum air temperature $\left(\mathrm{c}^{0}\right)$ and relative humidity $\%$ under plastic house in the first and second season are shown in Table (2).

Table 1. Physical and chemical properties of the experimental soil during the two seasons of study.

\begin{tabular}{llll}
\hline Item & Unit & 2017-2018 Season & 2018-2019 Season \\
\hline Coarse sand & $\%$ & 5.66 & 4.98 \\
Fine sand & $\%$ & 16.75 & 15.50 \\
Silt & $\%$ & 22.87 & 26.02 \\
Clay & $\%$ & 54.72 & 53.5 \\
Textural class & & Clay & Clay \\
Bulk density & $\mathrm{kg} / \mathrm{m} 3$ & 950 & 950 \\
pH & $(1: 2.5)$ & 7.02 & 7.18 \\
E.C $(1: 2.5)$ & $\mathrm{ds} / \mathrm{m}$ & 6.52 & 6.63 \\
Total nitrogen & $\mathrm{ppm}$. & 399 & 350 \\
Total phosphate & $\mathrm{ppm}$ & 9.9 & 9.5 \\
Total potassium & $\mathrm{ppm}$ & 506.68 & 505 \\
Total Fe & $\mathrm{ppm}$ & 5.10 & 5.25 \\
Total Mn & $\mathrm{ppm}$ & 1.33 & 1.76 \\
Total $\mathrm{Zn}$ & $\mathrm{ppm}$ & 3.09 & 2.88 \\
Total Cu & $\mathrm{ppm}$ & 4.78 & 4.01 \\
Ca++ & $(\mathrm{meq} / \mathrm{l})$ & 60 & 60 \\
Mg++ & )meq/l( & 23 & 22 \\
\hline
\end{tabular}




\begin{tabular}{llll}
\hline $\mathrm{Na}+$ & )meq/l( & 11 & 11.5 \\
$\mathrm{~K}+$ & )meq/l( & 2.4 & 2.5 \\
$\mathrm{Cl}-$ & )meq/l( & 7.7 & 7.4 \\
$\mathrm{HCo}^{3}-$ & )meq/l( & 2.5 & 2.4 \\
\hline
\end{tabular}

Table 2. Maximum and minimum air temperature $\left(\mathrm{c}^{0}\right)$ and relative humidity\% under plastic house in the first and second season.

\begin{tabular}{lllllllll}
\hline \multirow{3}{*}{ Months } & \multicolumn{2}{l}{ First season (2017-2018) } & \multicolumn{3}{l}{ Second season (2017-2018) } \\
\cline { 2 - 9 } & \multicolumn{2}{l}{ Temperature C } & \multicolumn{2}{c}{ Relative humidity } & \multicolumn{2}{c}{ Temperature C } & \multicolumn{3}{c}{ Relative humidity } \\
\cline { 2 - 9 } & Max. & Min. & Max. & Min. & Max. & Min. & Max. & Min. \\
\hline October & 38 & 21 & 90 & 40.3 & 39 & 22.3 & 91 & 39.9 \\
November & 37 & 22.2 & 91 & 44.5 & 38.7 & 23 & 92 & 41 \\
December & 36.9 & 14.2 & 90 & 36.5 & 37.5 & 14.5 & 90 & 37 \\
January & 33.4 & 14.1 & 89 & 24.6 & 34.5 & 13.9 & 89 & 40.2 \\
February & 35.5 & 14.5 & 90 & 25.3 & 35.7 & 14.1 & 89.5 & 40.1 \\
March & 36.3 & 16.7 & 90.3 & 39.1 & 35.8 & 18 & 91.5 & 41.9 \\
\hline
\end{tabular}

The experimental design was a randomized complete block, factorial, in 3 replicates. Factors of the experiment and their treatments were as follows:

(A) P-addition: three treatments of :(1) Super Phosphate $\left(16 \% \mathrm{P}_{2} \mathrm{O}_{5}\right)$, (2) Rock Phosphate $(26.3 \%$ $\left.\mathrm{P}_{2} \mathrm{O}_{5}\right)$, (3) Phosphoric acid $\left(56 \% \mathrm{P}_{2} \mathrm{O}_{5}\right)$ (designated as $\mathrm{P}_{1}, \mathrm{P}_{2}, \mathrm{P}_{3}$ respectively), the full dose of $\mathrm{P} 7.84 \mathrm{~g}$ $\mathrm{P} / \mathrm{m}^{2}$, (B) Bio fertilization two treatments: (1) no addition of bio fertilizer $\left(\mathrm{B}_{0}\right)$ and $(2)$ addition of bio fertilizer $\left(\mathrm{B}_{1}\right)$.The bio fertilizer is $\mathrm{P}$-dissolving bacteria (Bacillus megaterium).

Bacterial strain of P-dissolving bacteria (Bacillus megateriumvar phosphaticum) was obtained from the Unit of Bio-fertilizers, Faculty of Agriculture, Ain Shams University, Egypt. The bio fertilizer suspension was given through the soil in two doses: the first was with seed sowing and the second was added to soil 14 days after seeding at $21 / 360 \mathrm{~m}^{2}$ per once.

Calcium superphosphate $\quad\left(\mathbf{1 5 . 5 \%} \quad \mathbf{P}_{2} \mathrm{O}_{5}\right)$ was obtained from Abu Zaabal fertilizer and chemical Co., Egypt, added at $50 \mathrm{~g} / \mathrm{m}^{2}(18 \mathrm{~kg} /$ greenhouse $360 \mathrm{~m}^{2}$ ) before the planting.

Rock phosphate $\left(\mathbf{2 6 . 3 \%} \quad \mathbf{P}_{2} \mathbf{O}_{5}\right)$ was obtained from Abu Zaabal fertilizer and chemical Co., Egypt, added at $27 \mathrm{~g} / \mathrm{m}^{2}\left(9.7 \mathrm{~kg} /\right.$ greenhouse $\left.360 \mathrm{~m}^{2}\right)$ before the planting. Analysis of rock phosphate are shown in Table (3).

Phosphoric acid $\left(\mathbf{5 6} \% \mathbf{P}_{2} \mathbf{O}_{5}\right)$ was applied at 14.3 $\mathrm{mg} / \mathrm{m}^{2}\left(5.151\right.$ per greenhouse $\left.360 \mathrm{~m}^{2}\right)$. It was added with drip irrigation at three times started after one month from planting, with one month interval, during the two growing seasons.

Table 3. Chemical analysis of the experimental soil. of rock phosphate

\begin{tabular}{|c|c|c|}
\hline & Unit & \\
\hline pH & & 7.51 \\
\hline $\mathrm{EC}(1: 5)$ & $(\mathrm{dS} / \mathrm{m})$ & 2.73 \\
\hline Moisture content & $\%$ & 4.6 \\
\hline Dry matter & $\%$ & 95.4 \\
\hline Total N & $\%$ & 0.015 \\
\hline $\mathrm{SiO}_{2}$ & $\%$ & 3.83 \\
\hline $\mathrm{Al}_{2} \mathrm{O}_{3}$ & $\%$ & 0.28 \\
\hline $\mathrm{Fe}_{2} \mathrm{O}_{3}$ & $\%$ & 0.22 \\
\hline $\mathrm{TiO}_{2}$ & $\%$ & 0.02 \\
\hline $\mathrm{CaO}$ & $\%$ & 51.23 \\
\hline MgO & $\%$ & 0.68 \\
\hline MnO & $\%$ & 0.06 \\
\hline $\mathbf{K}_{2} \mathrm{O}$ & $\%$ & 0.04 \\
\hline $\mathrm{Na}_{2} \mathrm{O}$ & $\%$ & 0.61 \\
\hline $\mathrm{P}_{2} \mathrm{O}_{5}$ & $\%$ & 26.3 \\
\hline $\mathrm{SO}_{3}$ & $\%$ & 1.32 \\
\hline Cd & $\mathrm{Mg} / \mathrm{g}$ & 7.32 \\
\hline $\mathbf{N a}$ & $\mathrm{Mg} / \mathrm{g}$ & 952.8 \\
\hline
\end{tabular}

Data recorded: -

1- Vegetative growth characteristics
At full blooming stage (60 days from sowing) three plants from each experimental plot were taken and the following data were recorded. 
Plant height, number of leaves/plants, number of branches/plants, fresh and dry weight/ plant

2- Photosynthetic pigments: - the chlorophyll a,b and carotenoids from the fifth mature leaf from top was measured at 60 days from seed sowing were determined calorimetrically as described in A.O.A.C (1990).

Chemical constituents of plant foliage: - were determined in the dry weight of plant foliage at 60 days from seed sowing and then used to the following chemical constituents, total nitrogen, phosphorous, potassium, calcium and Magnesium percentages were determined according to ADAS/MAFF (1987), Watanabe and Olsen (1965) and Chapman and Pratt (1961), respectively.

3- Yield measurements: - at harvest, 70 days after seed sowing, green pods from each experiential unit were picked, weighed and the following yield components were estimated.

a- Early bods yield :- the yield which was collected from the first four harvests was expressed as early yield (early yield/ plant and $\mathrm{m}^{2}$ ).

b- Total pods yield :- included all the green pods which were picked all over the harvesting periods (total yield / plant and $\mathrm{m}^{2}$ ).

c- Marketable yield\%: (marketable yield/ total yield) 100

4- Chemical pods quality was determined as follow:

$$
\text { - }
$$

$\checkmark$ Total nitrogen:- it was assayed according to Pregl (1945), using the micro- kjeldahl apparatus. A factor of 6.25 was used for conversion of total nitrogen to protein percentage.

$\checkmark$ Phosphorus and potassium concentration as mentioned before in chemical constituents of leaves.

$\checkmark$ Fibers:- it was determined as g/100 g dry weight sample according to (A.O.A.C.,1990).

$\checkmark$ Total carbohydrate:- it was determined in dry weight sample according to Mgnetskietal. (1959).

Statistical analysis: All collected data in both season of study were subjected to analysis of variance as factorial experiments in design was a randomized complete block, Duncan's analysis was used to differentiate means according to Snedecor and Cochran (1991).

\section{Results and Discussions}

\section{Vegetative growth characteristics.}

Data presented in table (4) show the effect of different sources of phosphors as a soil application i.e Calcium super phosphate $\left(15.5 \% \mathrm{P}_{2} \mathrm{O}_{5}\right)$ at $50 \mathrm{~g} / \mathrm{m}_{2}$, Rock phosphate $\left(26.3 \% \quad \mathrm{P}_{2} \mathrm{O}_{5}\right)$ at $27 \mathrm{~g} / \mathrm{m}_{2}$, Phosphoric acid $\left(56 \% \mathrm{P}_{2} \mathrm{O}_{5}\right)$ at $14.3 \mathrm{mg} / \mathrm{m}^{2}$ at recommended dose with/ without bio fertilizer Bacillus megaterium var. phosphaticum "phosphate dissolving bacteria "PDB" as well as their interaction on vegetative growth parameters of snap bean plants growing under greenhouses during the two seasons of study.

It is evident from data in Table (4) that, there were significant differences in most studied morphological vegetative growth parameters of snap bean plants among the used different sources of phosphor fertilizing. In addition, using Phosphoric acid $\left(56 \% \mathrm{P}_{2} \mathrm{O}_{5}\right)$ fertilizer at the recommended dose of mineral fertilizer reflected significantly highest values in all measured vegetative growth aspects (plant height, number of leaves, number of branches, total fresh and dry weight/plant as well as leaf area ) of bean plants compared with rock phosphate at the recommended dose of mineral fertilizer which gave the lowest values in the two seasons of study. On the contrary, such differences did not reach the level of significance between phosphoric acid and calcium super phosphate in case of number of branches per plant in the two season.

As for the effect of bio fertilizer treatments, the same data in Table (4) indicate that fertilizing snap bean plants with Bio-Phosphorus fertilizer contained phosphate dissolving bacteria (PDB) (Bacillus megaterium var phosphaticum) at rate of 4 L/greenhouse applied alone at soil subsurface near the plant roots at two time started after two weeks from transplantation with one month interval at 2 $1 / 360 \mathrm{~m}^{2}$ increased all measured growth aspects expressed as plant height, number of leaves and branches/plant, fresh and dry weight of plant and leaf area per plant compared with the treatment without addition in the two seasons of study.

With regard to the effect of the interaction between (p) soil addition fertilizers and bio fertilizer(PDB), the same data in Table(4) indicate that fertilizing the plants with different sources $(p)$ plus (PDB) gave the highest values in most measure under study, fertilizing plants with phosphoric acid plus PDB gave the highest values in all growth aspects compared with other treatments during both seasons of study. The enhancing effect of phosphoric acid on vegetative growth may be due to the main role in reducing soil $\mathrm{pH}$, which can improve the availably of mineral elements and make them more soluble and available for absorption by plants and in turn increase the vegetative growth. Obtained results are in agreement with those reported byEl-bassiony (2003), El-zeiny (2007), Gharib et al. (2009) and Massoud et al. (2009).

\section{Chemical composition of plant foliage}

Data recorded in Table (5) show the effect of different sources of phosphor as a soil application i.e Calcium super phosphate $\left(15.5 \% \mathrm{P}_{2} \mathrm{O}_{5}\right)$ at $50 \mathrm{~g} / \mathrm{m}_{2}$, Rock phosphate $\left(26.3 \% \mathrm{P}_{2} \mathrm{O}_{5}\right)$ at $27 \mathrm{~g} / \mathrm{m}_{2}$, Phosphoric acid $\left(56 \% \mathrm{P}_{2} \mathrm{O}_{5}\right)$ at $14.3 \mathrm{mg} / \mathrm{m}^{2}$ at recommended dose with/ without bio fertilizer Bacillus megaterium var. phosphaticum "phosphate dissolving bacteria "PDB" 
as well as their interaction on chemical constituents of plant foliage during the two seasons of growth. Concerning to the effect of fertilization treatments, it's clear from such data that fertilizing snap bean plants with calcium super phosphate, rock phosphate and phosphoric acid of recommended dose show no significant differences in some determined chemical constituent of chlorophyll $\mathrm{a}+\mathrm{b}$, nitrogen, magnesium percentage in the both season and chlorophyll a, carotenoids and calcium in the first one. In this regard, fertilizer plants with phosphoric acid improved significantly phosphor, potassium percentage in both season and carotenoids and calcium percentage in second one followed by calcium super phosphate in both seasons of study.

Concerning the effect bio fertilizer treatments the same data in Table (5) indicate that, fertilizing snap bean plants with Bio-Phosphorus fertilizer contained phosphate dissolving bacteria (PDB) (Bacillus megaterium var phosphaticum) at rate of 4 L/greenhouse applied alone at soil subsurface near the plant roots at two time started after two weeks from transplantation with one month interval at 2 $1 / 360 \mathrm{~m}^{2}$ per increased all studied chemical constituents of plants that reached the level of significance during both seasons, without significant in case calcium and magnesium percentage in first season and nitrogen and magnesium percentage in second one Obtained results are in agreement with those reported by Massoud et al. (2009), Ahmed et al. (2013) and Sabry et al. (2017)

As for the effect of the interaction the same data in Table(5) indicate that fertilizing the plants with phosphoric acid plus PDB reflected the highest values in most measure i.e the photosynthetic pigments and phosphor percentage in both season of study as well as no significant in case of nitrogen, potassium, calcium and magnesium percentage in both season, On the other hand, fertilizing snap bean with rock phosphate of recommended dose without bio fertilizer gave the lowest values in all assayed aspects during both seasons of study. The simulative effect of $\mathrm{P}$ on $\mathrm{N}$ and $\mathrm{P}$ contents may be attributed to the high amount of available phosphorous and/ or the increase in absorbing efficiency of plant roots. . In this connection, the superiority of PDB and phosphoric acid in increasing the determined macroelements and total carbohydrate may be due to their role in fixing atmospheric nitrogen, reducing soil $\mathrm{pH}$ and increasing solubility of phosphors and potassium in root rizosphere and consequently increased nutrient uptake and accumulation by plants and also increased the photosynthetic pigments assimilation and their content in plant foliage Obtained results are in agreement with those reported by Ahmed $\boldsymbol{e t}$ al. (2013), Elbassiony (2003) and Sabry et al. (2017)

\section{Green pods yield and its components.}

Data in Table (6) indicate that there were a differences in all measure Green pods yield and its components of snap bean plants as a result of using different studied sources of phosphor fertilizer except early yield in both season and pod yield /plant in first one. Fertilizer plants by phosphoric acid gave the highest values in marketable yield and total yield $/ \mathrm{m}^{2}$ followed by fertilizing with calcium super phosphate. In this connection, using rock phosphate from recommended dose reflected the lowest values in produced green pods yield.

As for the effect of bio fertilizer treatments on total produced pods yield and its components, such data in Table (6) show that, fertilizing snap bean plants with Bio-Phosphorus fertilizer contained phosphate dissolving bacteria (PDB) significantly increased total produced pods yield and its components in both season compared with anther treatments without (PDB).

As for the effect of the interaction the same data in Table (6) indicate that fertilizing the plants with phosphoric acid plus PDB reflected the highest values in total produced green pods yield and its components in all measure i.e early yield, marketable yield and total pod yield in both season of study followed by fertilizing plants with calcium super phosphate plus (PDB) in both season. On the other hand, fertilizing snap bean with rock phosphate of recommended dose without bio fertilizer gave the lowest values in all assayed aspects during both seasons of study. In this connection, such increment effect of bio-phosphorus and phosphoric acid may be attributed to their positive effect on vegetative growth parameter (Table 4) and chemical constituents (Table5) which in turn reflected on number of flower formation and consequently increased the produced yield. Obtained results are in agreement with those reported by Elbassiony (2003), Elkatib et al. (2009), Massoud et al. (2009), Salem and midan (2012), Ahmed et al. (2013) and Meseretturuko et al. (2014).

\section{Chemical pods quality. \\ Physical pods quality}

Data in Table (7) show the effect of mineral fertilizer(p) sources as a soil application i.e Calcium super phosphate $\left(\begin{array}{lll}15.5 \% & \mathrm{P}_{2} \mathrm{O}_{5}\end{array}\right)$ at $50 \mathrm{~g} / \mathrm{m}_{2}$, Rock phosphate $\left(26.3 \% \mathrm{P}_{2} \mathrm{O}_{5}\right)$ at $27 \mathrm{~g} / \mathrm{m}_{2}$, Phosphoric acid $\left(56 \% \mathrm{P}_{2} \mathrm{O}_{5}\right)$ at $14.3 \mathrm{mg} / \mathrm{m}^{2}$ at recommended dose with/ without bio fertilizer Bacillus megaterium var. phosphaticum "phosphate dissolving bacteria "PDB" as well as their interaction on physical pods parameters expressed as average pod length, diameter, fresh and dry weight of pod and dry matter during the two seasons of study

Data in Table (7) indicate that there were a differences in all measured physical pods trails of snap bean plants as a result of using different studied sources of phosphor fertilizer. In this regards, such difference did not reach the level of significant in case of pod length, pod diameter in both season, also pod fresh and dry weight in first one season only. 
However, using super phosphate at the recommended dose reflected the highest values of pod fresh and dry weight in second season. As for the effect of bio fertilizer treatments on physical pod quality parameters, the same data in Table (7) indicate that, fertilizing snap bean plants with Bio-Phosphorus fertilizer contained phosphate dissolving bacteria (PDB) significantly increased all measured pod parameters with significantly in case of pod fresh and dry weight in first season and pod length, pod diameter and pod fresh weight in second one .

With regard to the effect of the interaction, the same data in Table(7) indicate that average all measured pod traits significantly affected by interaction treatments except pod length in both season and pod diameter in first season. In this respect, fertilizing of snap bean plants with phosphoric acid as soil application from recommended dose plus PDB gave the highest value of all measure physical quality compared with others interaction treatments, followed by using calcium super phosphate plus PDB and phosphoric acid without (PDB). The increment effect of biophosphorus and phosphoric acid fertilizer on physical pod quality traits may be attributed to increasing nitrogen, phosphorus, potassium uptake and total carbohydrates assimilation which affect the increasing anabolic assimilation products which consequently reflected on green pod parameters. Obtained results are in agreement with those reported by El-zeiny (2007), Salem (2012) and Ahmed et al. (2013).
Chemical pods constituent's quality.

With regards to the effect of fertilization treatments, data in Table(8) showed that there were a differences among the fertilization treatments in all measured chemical pods quality expressed as fertilizer plants with phosphoric acid gave the highest values of all measure quality parameters i.e. carbohydrate, protein, phosphor, potassium and T.s.s.

Data in Table (8) revealed that the effect of bio fertilizer treatments on increased all measured of as carbohydrate, protein, fiber, phosphor, potassium and T.s.s percentages during both seasons of study without significant in case of fiber in both season and potassium in second one. Compared with the other treatment.

As for the effect of the interaction the same date in Table (8) indicate that fertilizing bean plants with phosphoric acid as soil application from recommended dose plus PDB reflected the highest values of carbohydrate, protein, phosphor, potassium and T.s.s percentages during both seasons except potassium percentage in both season followed by fertilizing bean plant with calcium super phosphate plus PDB in two season. while the lowest fiber percentage was recorded as a result of using phosphoric acid plus PDB during the two seasons of growth. Bio phosphors with chemical phosphorus fertilizer increased pods protein, because nutrients absorption capability and plant absorption balance increased by phosphate-solubilizing microorganisms. Obtained results are in agreement with those reported by Elbassiony(2003), El-zeiny (2007), Massoud $e t$ al. (2009), Elkatib et al. (2009) and Salem (2012). 
Table 4. Effect of mineral (P) fertilizers sources bio fertilizer treatments as well as their interactions on vegetative growth of plant foliage of snap bean plants during the two seasons 2017- 2018 and 2018 -2019

\begin{tabular}{|c|c|c|c|c|c|c|c|c|c|c|c|c|}
\hline \multirow{2}{*}{ Treatments } & \multicolumn{6}{|c|}{ First season } & \multicolumn{6}{|c|}{ Second season } \\
\hline & $\begin{array}{l}\text { Plant } \\
\text { height } \\
(\mathrm{cm})\end{array}$ & $\begin{array}{l}\text { NO. of } \\
\text { leaves/ } \\
\text { plant }\end{array}$ & $\begin{array}{l}\text { No. of } \\
\text { branches/plant }\end{array}$ & $\begin{array}{l}\text { Total } \\
\text { fresh } \\
\text { weight } \\
\text { (g/plant) }\end{array}$ & $\begin{array}{l}\text { Total } \\
\text { dry } \\
\text { weight } \\
\text { (g/plant) }\end{array}$ & $\begin{array}{l}\text { Leaf } \\
\text { area/plant } \\
\left(\mathrm{cm}^{2}\right)\end{array}$ & $\begin{array}{l}\text { Plant } \\
\text { height } \\
(\mathrm{cm})\end{array}$ & $\begin{array}{l}\text { NO. of } \\
\text { leaves/plant }\end{array}$ & $\begin{array}{l}\text { No. of } \\
\text { branches/plant }\end{array}$ & $\begin{array}{l}\text { Total } \\
\text { fresh } \\
\text { weight } \\
\text { (g/plant) }\end{array}$ & $\begin{array}{l}\text { Total } \\
\text { dry } \\
\text { weight } \\
\text { (g/plant) }\end{array}$ & $\begin{array}{l}\text { Leaf } \\
\text { area/plant } \\
\left(\mathrm{cm}^{2}\right)\end{array}$ \\
\hline \multicolumn{13}{|c|}{ Soil application of P-sources } \\
\hline Super Phosphate & $\begin{array}{l}289.2 \\
\mathrm{ab}\end{array}$ & $\begin{array}{l}14.835 \\
b\end{array}$ & $3.54 \mathrm{a}$ & $221.3 \mathrm{~b}$ & $\begin{array}{l}43.005 \\
b\end{array}$ & $77.735 \mathrm{ab}$ & $276.1 \mathrm{~b}$ & $15.5 \mathrm{a}$ & $2.725 \mathrm{a}$ & $205.05 \mathrm{a}$ & $33.055 \mathrm{a}$ & $68.915 \mathrm{ab}$ \\
\hline Rock Phosphate & $286.1 \mathrm{~b}$ & $\begin{array}{l}15.535 \\
b\end{array}$ & $2.995 \mathrm{~b}$ & $212 \mathrm{c}$ & $\begin{array}{l}43.555 \\
b\end{array}$ & $74.415 \mathrm{~b}$ & $\begin{array}{l}276.15 \\
b\end{array}$ & $14.33 b$ & $2.61 \mathrm{~b}$ & $185.35 \mathrm{~b}$ & $30.11 \mathrm{~b}$ & $65.135 \mathrm{~b}$ \\
\hline Phosphoric acid & $295 \mathrm{a}$ & $16.12 \mathrm{a}$ & $3.76 \mathrm{a}$ & $217.85 \mathrm{a}$ & $45.445 \mathrm{a}$ & $93.1 \mathrm{a}$ & $\begin{array}{l}290.35 \\
\mathrm{a}\end{array}$ & $15.83 \mathrm{a}$ & $2.945 \mathrm{a}$ & $201.5 \mathrm{a}$ & $33.055 \mathrm{a}$ & $79.915 \mathrm{a}$ \\
\hline \multicolumn{13}{|c|}{ Inoculation with P-dissolving bacteria (Bacillus megaterium) } \\
\hline $\begin{array}{l}\text { Without } \\
\text { fertilizer }\end{array}$ & $\begin{array}{l}278.93 \\
b\end{array}$ & $15.28 \mathrm{~b}$ & $3.02 \mathrm{~b}$ & $\begin{array}{l}205.23 \\
\mathrm{~b}\end{array}$ & $41.33 \mathrm{~b}$ & $75.38 \mathrm{~b}$ & $273.7 \mathrm{~b}$ & $14.7 \mathrm{~b}$ & $2.48 \mathrm{~b}$ & $188.1 \mathrm{~b}$ & $30.26 \mathrm{~b}$ & $67.27 \mathrm{~b}$ \\
\hline With bio fertilizer & $301.3 \mathrm{a}$ & $15.71 \mathrm{a}$ & $3.85 \mathrm{a}$ & $228.87 \mathrm{a}$ & $46.67 \mathrm{a}$ & $88.12 \mathrm{a}$ & $\begin{array}{l}288.03 \\
\mathrm{a}\end{array}$ & $15.74 \mathrm{a}$ & $3.04 \mathrm{a}$ & $206.5 \mathrm{a}$ & $33.89 \mathrm{a}$ & $75.38 \mathrm{a}$ \\
\hline \multicolumn{13}{|c|}{ Soil application of P-sources X Inoculation with P-dissolving bacteria (Bacillus megaterium) } \\
\hline $\begin{array}{ll}\stackrel{ }{0} & \text { Super } \\
& \text { Phosphate }\end{array}$ & $276.3 \mathrm{c}$ & $15.67 \mathrm{~b}$ & $3.31 \mathrm{ab}$ & $218.2 \mathrm{ab}$ & $42.45 \mathrm{~b}$ & $76.3 \mathrm{~b}$ & $\begin{array}{l}274.4 \\
\text { bc }\end{array}$ & $15.67 \mathrm{ab}$ & $2.56 \mathrm{~b}$ & $197.3 \mathrm{ab}$ & $32.33 \mathrm{bc}$ & $67.13 \mathrm{bc}$ \\
\hline \multirow{5}{*}{ 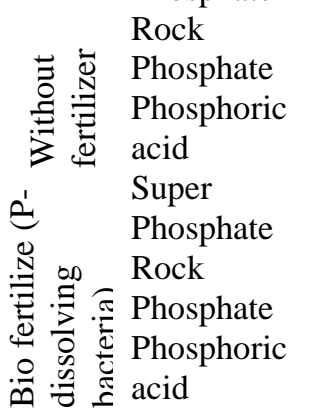 } & $274.4 \mathrm{c}$ & $15.5 \mathrm{bc}$ & $2.44 \mathrm{~b}$ & $193.6 \mathrm{c}$ & $39.33 \mathrm{c}$ & $68.63 \mathrm{c}$ & $266.7 \mathrm{c}$ & $13.9 \mathrm{c}$ & $2.33 \mathrm{~b}$ & $179 \mathrm{~b}$ & $27.89 \mathrm{~d}$ & $65.57 \mathrm{bc}$ \\
\hline & $\begin{array}{l}286.1 \\
\mathrm{bc}\end{array}$ & $\begin{array}{l}14.67 \\
\mathrm{~cd}\end{array}$ & $3.3 \mathrm{ab}$ & $203.9 \mathrm{bc}$ & $42.22 \mathrm{~b}$ & $81.2 \mathrm{~b}$ & $280 \mathrm{bc}$ & $14.53 \mathrm{bc}$ & $2.56 \mathrm{~b}$ & $188 \mathrm{~b}$ & $30.55 \mathrm{~cd}$ & $69.1 \mathrm{bc}$ \\
\hline & $\begin{array}{l}302.2 \\
\mathrm{ab}\end{array}$ & $14 \mathrm{~d}$ & $3.77 \mathrm{ab}$ & $224.4 \mathrm{a}$ & $43.56 \mathrm{~b}$ & $79.17 \mathrm{~b}$ & $\begin{array}{l}277.8 \\
\text { bc }\end{array}$ & $15.33 \mathrm{bc}$ & $2.89 \mathrm{ab}$ & $212.8 \mathrm{a}$ & $33.78 \mathrm{ab}$ & $70.7 \mathrm{~b}$ \\
\hline & $\begin{array}{l}297.8 \\
\mathrm{ab}\end{array}$ & $\begin{array}{l}15.57 \\
\mathrm{bc}\end{array}$ & $3.55 \mathrm{ab}$ & $230.4 \mathrm{a}$ & $47.78 \mathrm{a}$ & $80.2 \mathrm{~b}$ & $\begin{array}{l}285.6 \\
\mathrm{ab}\end{array}$ & $14.77 \mathrm{bc}$ & $2.89 a b$ & $191.7 \mathrm{ab}$ & $32.33 \mathrm{bc}$ & $64.7 \mathrm{c}$ \\
\hline & $303.9 \mathrm{a}$ & $17.57 \mathrm{a}$ & $4.22 \mathrm{a}$ & $231.8 \mathrm{a}$ & $48.67 \mathrm{a}$ & $105 \mathrm{a}$ & $300.7 \mathrm{a}$ & $17.13 \mathrm{a}$ & $3.33 \mathrm{a}$ & $215 \mathrm{a}$ & $35.56 \mathrm{a}$ & $90.73 \mathrm{a}$ \\
\hline
\end{tabular}


Table 5. Effect of mineral(P) fertilizers sources bio fertilizer treatments as well as their interactions on chemical constituents of plant foliage of snap bean plants during the two seasons 2017- 2018 and 2018 -2019.

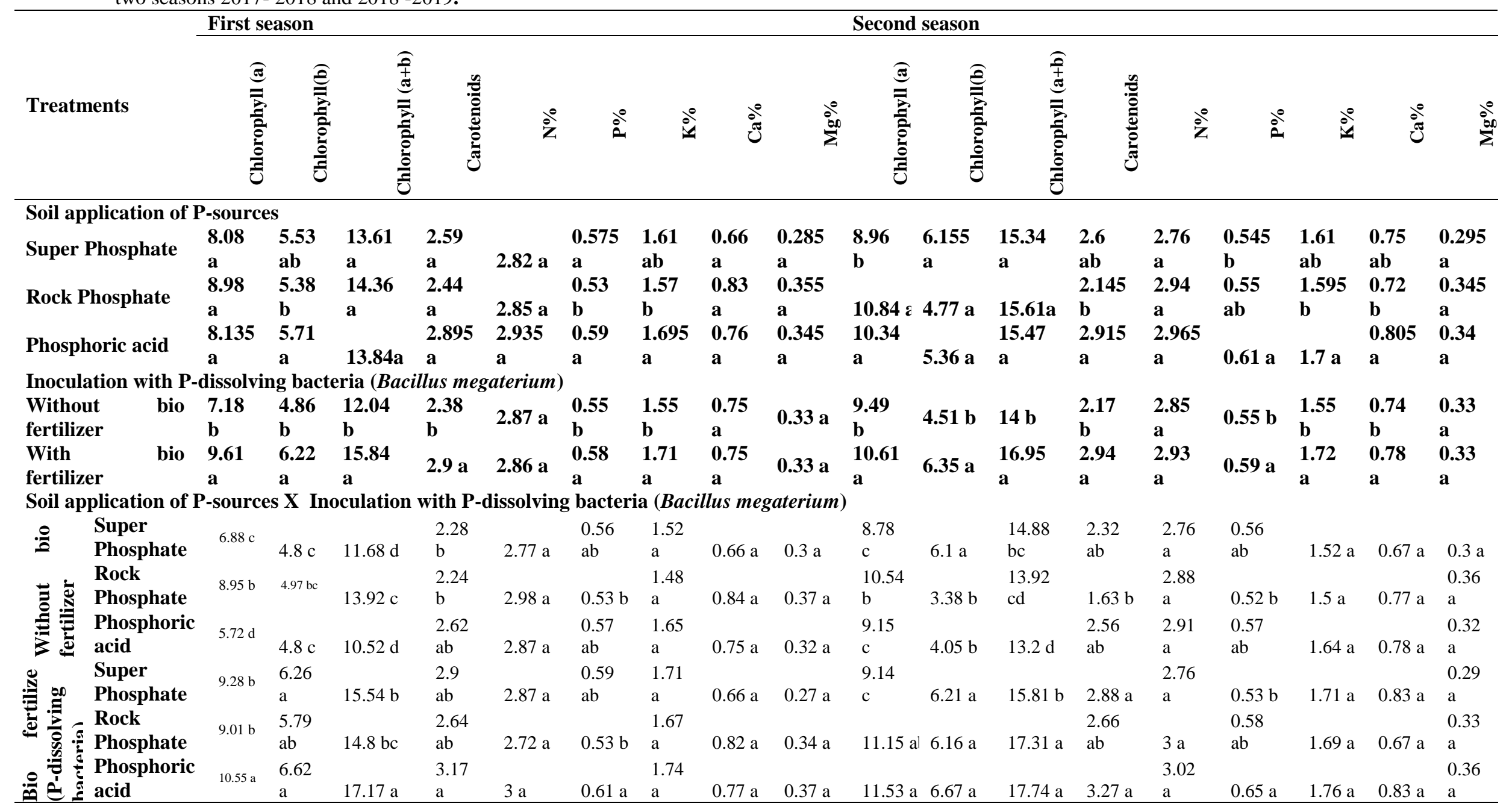


Table 6. Effect of mineral(P) fertilizers sources bio fertilizer treatments as well as their interactions on green pods yield and its components of plant foliage of snap bean plants during the two seasons 2017- 2018 and $2018-2019$.

\begin{tabular}{|c|c|c|c|c|c|c|c|c|}
\hline \multirow[b]{2}{*}{ Treatments } & \multicolumn{4}{|l|}{ First season } & \multicolumn{4}{|l|}{ Second season } \\
\hline & $\begin{array}{l}\begin{array}{l}\text { Early } \\
(\mathrm{g} / \mathrm{m} 2)\end{array} \\
\end{array}$ & $\begin{array}{l}\text { Marketable } \\
\text { yield/m2 }\end{array}$ & $\begin{array}{l}\text { Total Pod yield } \\
(\mathrm{g} / \mathrm{m} 2)\end{array}$ & $\begin{array}{ll}\begin{array}{l}\text { Pod } \\
\text { (g/plant) }\end{array} & \text { yields } \\
\end{array}$ & \begin{tabular}{ll|}
$\begin{array}{l}\text { Early } \\
(\mathrm{g} / \mathrm{m} 2)\end{array}$ & yield \\
\end{tabular} & $\begin{array}{l}\text { Marketable } \\
\text { yield/m2 }\end{array}$ & $\begin{array}{l}\text { Total Pod } \\
\text { yield }(\mathrm{g} / \mathrm{m} 2)\end{array}$ & $\begin{array}{l}\text { Pod yields } \\
\text { (g/plant) }\end{array}$ \\
\hline \multicolumn{9}{|l|}{ Soil application of P-sources } \\
\hline Super Phosphate & 819 a & $5281 \mathrm{a}$ & $6515 \mathrm{a}$ & $1319.15 \mathrm{a}$ & $809.35 \mathrm{a}$ & $4868.5 \mathrm{a}$ & $5962.5 \mathrm{ab}$ & $1209.5 \mathrm{ab}$ \\
\hline Rock Phosphate & $703.15 \mathrm{a}$ & $4860 \mathrm{~b}$ & $6043.5 b$ & $1203.35 \mathrm{a}$ & $830.5 \mathrm{a}$ & $4564.5 \mathrm{~b}$ & $5760 \mathrm{~b}$ & $1149.2 \mathrm{~b}$ \\
\hline Phosphoric acid & $810.5 \mathrm{a}$ & $5251 \mathrm{a}$ & $6602.5 \mathrm{a}$ & 1310.85 a & $852.35 \mathrm{a}$ & $4886.5 \mathrm{a}$ & 6295 a & $1245 \mathrm{a}$ \\
\hline \multicolumn{9}{|c|}{ Inoculation with P-dissolving bacteria (Bacillus megaterium) } \\
\hline Without bio fertilizer & $716.2 \mathrm{~b}$ & $4907.3 \mathrm{~b}$ & $6080.6 \mathrm{~b}$ & $1216.4 \mathrm{~b}$ & $756.43 \mathrm{~b}$ & $4472.3 \mathrm{~b}$ & $5581.67 \mathrm{~b}$ & $1116.47 \mathrm{~b}$ \\
\hline With bio fertilizer & 838.9 a & $5354 \mathrm{a}$ & $6693.3 \mathrm{a}$ & $1339.1 \mathrm{a}$ & $905.03 \mathrm{a}$ & $5074 \mathrm{a}$ & $6430 \mathrm{a}$ & $1286 \mathrm{a}$ \\
\hline \multicolumn{9}{|c|}{ Soil application of P-sources X Inoculation with P-dissolving bacteria (Bacillus megaterium) } \\
\hline $0 \mathrm{~N}$ Super Phosphate & $767.3 \mathrm{c}$ & $5093 \mathrm{ab}$ & $5237 \mathrm{c}$ & $1267.5 \mathrm{ab}$ & $771 \mathrm{c}$ & $4665 \mathrm{c}$ & $5680 \mathrm{c}$ & $1164 \mathrm{c}$ \\
\hline Rock Phosphate & $634 \mathrm{~d}$ & $4608 \mathrm{c}$ & $6335 b$ & $1134.2 \mathrm{~b}$ & $706.3 \mathrm{~d}$ & $4181 \mathrm{~d}$ & $6245 \mathrm{~b}$ & $1049.4 \mathrm{~d}$ \\
\hline$\exists \equiv \doteq$ Phosphoric acid & $747.3 \mathrm{c}$ & $5021 \mathrm{~b}$ & $6670 \mathrm{a}$ & $1247.5 \mathrm{ab}$ & $826.7 \mathrm{~b}$ & $4571 \mathrm{c}$ & $5820 \mathrm{c}$ & $1136 \mathrm{c}$ \\
\hline$\therefore \quad$ Super Phosphate & $870.7 \mathrm{ab}$ & 5469 a & $6850 \mathrm{a}$ & $1370.8 \mathrm{a}$ & $954.7 \mathrm{a}$ & $5072 \mathrm{ab}$ & $5245 \mathrm{~d}$ & $1255 \mathrm{~b}$ \\
\hline 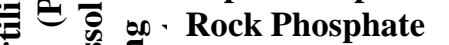 & $772.3 \mathrm{bc}$ & $5112 \mathrm{ab}$ & $6360 \mathrm{~b}$ & $1272.5 \mathrm{ab}$ & $792 \mathrm{bc}$ & $4948 \mathrm{~b}$ & $6275 \mathrm{~b}$ & $1249 \mathrm{~b}$ \\
\hline ๑ & $873.7 \mathrm{a}$ & $5481 \mathrm{a}$ & $6870 \mathrm{a}$ & $1374.2 \mathrm{a}$ & $933.7 \mathrm{a}$ & $5202 \mathrm{a}$ & $6770 \mathrm{a}$ & $1354 \mathrm{a}$ \\
\hline
\end{tabular}


Table 7. Effect of mineral (P) fertilizers sources bio fertilizer treatments as well as their interactions on physical fruit quality of plant foliage of snap bean plants during the two seasons 2017- 2018 and $2018-2019$.

\begin{tabular}{|c|c|c|c|c|c|c|c|c|c|}
\hline \multirow{3}{*}{ Treatments } & & \multicolumn{4}{|l|}{ First season } & \multicolumn{4}{|l|}{ Second season } \\
\hline & & $\begin{array}{l}\text { Pod length } \\
(\mathrm{cm})\end{array}$ & $\begin{array}{l}\text { Pod } \\
\text { diameter } \\
\text { (cm) }\end{array}$ & $\begin{array}{l}\text { Pod fresh } \\
\text { weight(g) }\end{array}$ & $\begin{array}{l}\text { Pod dry } \\
\text { weight }(g)\end{array}$ & $\begin{array}{l}\text { Pod length } \\
(\mathrm{cm})\end{array}$ & $\begin{array}{l}\text { Pod } \\
\text { diameter } \\
\text { (cm) }\end{array}$ & $\begin{array}{l}\text { Pod fresh } \\
\text { weight(g) }\end{array}$ & $\begin{array}{l}\text { Pod dry } \\
\text { weight(g) }\end{array}$ \\
\hline & & \multicolumn{8}{|c|}{ Soil application of P-sources } \\
\hline \multicolumn{2}{|c|}{ Super Phosphate } & $14.69 \mathrm{a}$ & $0.845 \mathrm{a}$ & $8.93 \mathrm{a}$ & $0.885 \mathrm{a}$ & $13.79 \mathrm{a}$ & $0.72 \mathrm{a}$ & $9.365 \mathrm{a}$ & $0.725 \mathrm{a}$ \\
\hline \multicolumn{2}{|c|}{ Rock Phosphate } & $14.60 \mathrm{a}$ & $0.835 \mathrm{a}$ & $8.595 \mathrm{a}$ & $0.855 b$ & $13.94 \mathrm{a}$ & $0.71 \mathrm{a}$ & $8.7 \mathrm{~b}$ & $0.715 \mathrm{~b}$ \\
\hline \multicolumn{2}{|l|}{ Phosphoric acid } & $14.86 \mathrm{a}$ & $0.855 \mathrm{a}$ & $8.78 \mathrm{a}$ & $0.85 \mathrm{~b}$ & $14.115 \mathrm{a}$ & $0.72 \mathrm{a}$ & $8.695 \mathrm{~b}$ & $0.73 \mathrm{a}$ \\
\hline & & \multicolumn{8}{|c|}{ Inoculation with P-dissolving bacteria (Bacillus megaterium) } \\
\hline \multirow{2}{*}{\multicolumn{2}{|c|}{$\begin{array}{l}\text { Without bio fertilizer } \\
\text { With bio fertilizer }\end{array}$}} & $14.63 \mathrm{a}$ & $0.84 \mathrm{a}$ & $8.45 \mathrm{~b}$ & $0.83 \mathrm{~b}$ & $13.64 \mathrm{~b}$ & $0.69 \mathrm{~b}$ & $8.55 \mathrm{~b}$ & $0.7 \mathrm{a}$ \\
\hline & & $14.81 \mathrm{a}$ & $0.85 \mathrm{a}$ & $9.08 \mathrm{a}$ & $0.89 \mathrm{a}$ & $14.26 \mathrm{a}$ & $0.75 \mathrm{a}$ & $9.29 \mathrm{a}$ & $0.75 \mathrm{a}$ \\
\hline \multicolumn{10}{|c|}{ Soil application of P-sources X Inoculation with P-dissolving bacteria (Bacillus megaterium) } \\
\hline \multirow{5}{*}{ 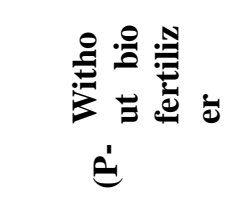 } & Super Phosphate & $14.72 \mathrm{a}$ & 0.84 a & $8.8 \mathbf{a b}$ & $0.82 \mathrm{c}$ & $13.69 \mathrm{a}$ & 0.69 bc & $8.4 \mathrm{c}$ & $0.69 \mathrm{c}$ \\
\hline & Rock Phosphate & $14.55 \mathrm{a}$ & 0.85 a & $8.23 \mathrm{~b}$ & 0.85 bc & 13.47 a & $0.68 \mathrm{c}$ & $8.56 \mathrm{bc}$ & 0.7 bc \\
\hline & Phosphoric acid & $14.61 \mathrm{a}$ & $0.82 \mathrm{a}$ & $8.33 \mathrm{~b}$ & $0.83 \mathrm{c}$ & $13.76 \mathrm{a}$ & 0.69 bc & 8.7 bc & 0.7 bc \\
\hline & Super Phosphate & $14.67 \mathrm{a}$ & $0.85 \mathrm{a}$ & $9.06 \mathrm{a}$ & $0.89 \mathrm{ab}$ & $13.89 \mathrm{a}$ & $0.76 \mathrm{a}$ & $9 \mathrm{~b}$ & $0.74 \mathrm{abc}$ \\
\hline & Rock Phosphate & $14.66 \mathrm{a}$ & $0.82 \mathrm{~b}$ & $8.96 \mathrm{a}$ & $0.85 \mathrm{bc}$ & $14.41 \mathrm{a}$ & $0.74 \mathrm{ab}$ & $8.83 \mathrm{bc}$ & $0.75 \mathrm{ab}$ \\
\hline \multirow{2}{*}{ 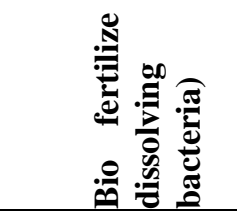 } & Phosphoric acid & & & & & & & & \\
\hline & & $15.11 \mathrm{a}$ & $0.89 \mathrm{a}$ & $9.23 \mathrm{a}$ & $0.94 \mathrm{a}$ & $14.47 \mathrm{a}$ & $0.76 \mathrm{a}$ & $10.03 \mathrm{a}$ & $0.76 \mathrm{a}$ \\
\hline
\end{tabular}


Table 8. Effect of mineral(P) fertilizers sources bio fertilizer treatments as well as their interactions on physical fruit quality of plant foliage of snap bean plants during the two seasons 2017- 2018 and $2018-2019$.

\begin{tabular}{|c|c|c|c|c|c|c|c|c|c|c|c|c|c|}
\hline \multirow{3}{*}{\multicolumn{2}{|c|}{ Treatments }} & \multicolumn{6}{|c|}{ First season } & \multicolumn{6}{|c|}{ Second season } \\
\hline & & 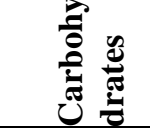 & تี & 㐫 & A & $\underline{1}$ & $\stackrel{n}{\stackrel{n}{0}}$ & 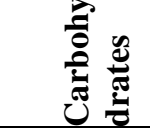 & ع & $\stackrel{\grave{d}}{\grave{E}}$ & A & $\underline{4}$ & $\stackrel{n}{:}$ \\
\hline & & \multicolumn{12}{|c|}{ Soil application of $\mathbf{P}$-sources } \\
\hline \multicolumn{2}{|c|}{ Super Phosphate } & $22.56 \mathrm{a}$ & $19.1 \mathrm{a}$ & $9.52 \mathrm{a}$ & $0.615 \mathrm{ab}$ & $1.92 \mathrm{a}$ & $6.5 \mathrm{ab}$ & $22.675 \mathrm{a}$ & $18.86 \mathrm{a}$ & $9.28 \mathrm{a}$ & $0.62 \mathrm{a}$ & $1.62 \mathrm{a}$ & $6.615 \mathrm{a}$ \\
\hline \multicolumn{2}{|c|}{ Rock Phosphate } & $21.62 b$ & $17.55 \mathrm{~b}$ & $9.68 \mathrm{a}$ & $0.575 \mathrm{~b}$ & $1.655 \mathrm{~b}$ & $6.05 \mathrm{~b}$ & $21.725 \mathrm{c}$ & $\begin{array}{l}18.13 \\
b\end{array}$ & $9.28 \mathrm{a}$ & $0.645 \mathrm{a}$ & $1.75 \mathrm{a}$ & $6.37 \mathrm{~b}$ \\
\hline \multicolumn{2}{|c|}{ Phosphoric acid } & $22.24 \mathrm{a}$ & $19.38 \mathrm{a}$ & $9.095 \mathrm{~b}$ & $0.64 \mathrm{a}$ & $1.965 \mathrm{a}$ & $6.89 \mathrm{a}$ & $22.34 \mathrm{~b}$ & $\begin{array}{l}18.98 \\
a\end{array}$ & $9.025 \mathrm{~b}$ & $0.605 \mathrm{a}$ & $2.03 \mathrm{a}$ & $6.665 \mathrm{a}$ \\
\hline & & \multicolumn{12}{|c|}{ Inoculation with P-dissolving bacteria (Bacillus megaterium) } \\
\hline \multicolumn{2}{|c|}{ Without bio fertilizer } & $21.12 \mathrm{~b}$ & $18.16 b$ & $9.45 \mathrm{a}$ & $0.59 \mathrm{~b}$ & $1.8 \mathrm{a}$ & $6.27 \mathrm{~b}$ & $21.24 b$ & $\begin{array}{l}17.79 \\
b\end{array}$ & $9.25 \mathrm{a}$ & $0.62 \mathrm{a}$ & $1.83 \mathrm{a}$ & $6.37 \mathrm{~b}$ \\
\hline \multicolumn{2}{|c|}{ With bio fertilizer } & $23.16 \mathrm{a}$ & $19.2 \mathrm{a}$ & $9.41 \mathrm{a}$ & $0.63 \mathrm{a}$ & $1.89 \mathrm{a}$ & $6.69 \mathrm{a}$ & $23.26 \mathrm{a}$ & $\begin{array}{l}19.53 \\
\mathrm{a}\end{array}$ & $9.14 b$ & $0.62 \mathrm{a}$ & $1.77 \mathrm{a}$ & $6.73 \mathrm{a}$ \\
\hline \multirow[b]{2}{*}{$\stackrel{\varrho}{\varrho}$} & & \multicolumn{12}{|c|}{ Soil application of P-sources X Inoculation with P-dissolving bacteria (Bacillus megaterium) } \\
\hline & $\begin{array}{l}\text { Super } \\
\text { Phosphate } \\
\text { Rock }\end{array}$ & $21.08 \mathrm{~b}$ & $18.43 \mathrm{ab}$ & $9.53 \mathrm{ab}$ & $0.59 \mathrm{a}$ & $1.87 \mathrm{abc}$ & $6.3 \mathrm{c}$ & $21.19 \mathrm{~b}$ & $17.93 \mathrm{bc}$ & $9.44 \mathrm{a}$ & $0.66 \mathrm{a}$ & $1.64 \mathrm{a}$ & $6.35 \mathrm{~b}$ \\
\hline \multirow{2}{*}{ 氧 } & $\begin{array}{l}\text { Phosphate } \\
\text { Phosphoric }\end{array}$ & $21.18 \mathrm{~b}$ & $17.47 \mathrm{~b}$ & $9.7 \mathrm{a}$ & $0.56 \mathrm{a}$ & $1.64 \mathrm{c}$ & $5.8 \mathrm{~d}$ & $21.27 \mathrm{~b}$ & $17.7 \mathrm{c}$ & $9.19 \mathrm{ab}$ & $0.6 \mathrm{a}$ & $1.83 \mathrm{a}$ & $6.32 \mathrm{~b}$ \\
\hline & $\begin{array}{l}\text { acid } \\
\text { Super }\end{array}$ & $21.11 \mathrm{~b}$ & $18.57 \mathrm{ab}$ & $9.13 \mathrm{~b}$ & $0.61 \mathrm{a}$ & $1.89 \mathrm{abc}$ & $6.7 \mathrm{~b}$ & $21.25 \mathrm{~b}$ & $17.73 \mathrm{bc}$ & $9.11 \mathrm{ab}$ & $0.61 \mathrm{a}$ & $2.03 \mathrm{a}$ & $6.44 \mathrm{~b}$ \\
\hline \multirow{3}{*}{ 苞 } & $\begin{array}{l}\text { Phosphate } \\
\text { Rock }\end{array}$ & $24.05 \mathrm{a}$ & $19.77 \mathrm{ab}$ & $9.51 \mathrm{ab}$ & $0.64 \mathrm{a}$ & $1.97 \mathrm{ab}$ & $6.7 \mathrm{~b}$ & $24.16 \mathrm{a}$ & $19.8 \mathrm{ab}$ & $9.12 \mathrm{ab}$ & $0.58 \mathrm{a}$ & $1.6 \mathrm{a}$ & $6.88 \mathrm{a}$ \\
\hline & Phosphate & $22.07 \mathrm{ab}$ & $17.63 \mathrm{~b}$ & $9.66 \mathrm{a}$ & $0.59 \mathrm{a}$ & $1.67 \mathrm{bc}$ & $6.3 \mathrm{c}$ & $22.18 \mathrm{ab}$ & $18.57 \mathrm{abc}$ & $9.37 \mathrm{a}$ & $0.69 \mathrm{a}$ & $1.67 \mathrm{a}$ & $6.42 \mathrm{~b}$ \\
\hline & acid & $23.37 \mathrm{ab}$ & $20.2 \mathrm{a}$ & $9.06 \mathrm{~b}$ & $0.67 \mathrm{a}$ & $2.04 \mathrm{a}$ & $7.08 \mathrm{a}$ & $23.43 \mathrm{ab}$ & $20.23 \mathrm{a}$ & $8.94 \mathrm{~b}$ & $0.6 \mathrm{a}$ & $2.03 \mathrm{a}$ & $6.89 \mathrm{a}$ \\
\hline
\end{tabular}


References

A.O.A.C. (1990).Official Methods of Analysis of the Association of Official Analytical Chemists. 15th ed. Published by the Association of Official Analytical Chemists, Anlington, Virginia 2201, USA.

ADAS/MAFF, 1987. The analysis of agricultural material book. 427, 3rd edition HMSO. London.

Adetunji, M.T., Atayese, M.O. and Soretire, A.A. (2005). Relative effectiveness of three phosphate rock samples for maize and soybean production. Nig. J. Soil Sci., 15(2): 77-83.

Ahmed, A.M., Gheeth, R. H. M. and Galal, R. M. 2013. Influence of organic manures and rock phosphate combined with feldspar on growth, yield and yield components of bean (Phaseolus vulgaris L.). Assiut J. Agric. Sci., 44(2) :71-89.

Akande M.O., Adediran J.A., Oluwatoyinbo F.I., Makinde E.A., Adetunji M.T.(2008). Suitability of poultry manure amended Sokoto rock phosphate on growth, nutrient uptake and yield of chilli pepper (Capsicum fruitscens L) Niger. J. Soil Sci. ;18:167-174.

Awasthi, R., Tewari, R. and Nayyar, H. 2011. Synergy between plants and P-Solubilizing microbes in soils: Effects on growth and physiology of crops. Inter Res J Microbiol. 2: 484-503.

Black, C.A. 1982. Methods of soil analysis. partz. American Society of Agronomy, I N C., publisher, Madison, Wisconsin, USA.

Chapman, H.D. and Pratt, P.F. 1961. Methods of analysis for soils, plants and waters. University of California, Los Angeles, 60-61, 150-179.

El-Bassiony, A.M. 2003. Response of some bean (Phaseolus vulgaris, L.) Cultivars to organic and bio- fertilizer. Ph.D Thesis., Faculty of Agri., Ain Shams Univ.

El-Bassiony, A.M. 2003. Response of some bean (Phaseolus vulgaris, L.) Cultivars to organic and bio- fertilizer. Ph.D Thesis., Faculty of Agri., Ain Shams Univ.

Elkhatib, H.A., Gabr, S.M., Radwan, F.I. and Abo El-Ali, R.F. 2009. Differential effects of mycorrhizal fungi and phosphate solubilizing bacteria and their potential for stimulating plant growth and seed yield of common bean. Alex., Sci., exchange j., 30, no.1january-march.

El-zeiny, O.A.H. 2007. Effect of bio-fertilizers and root exudates of two weeds as a source of natural growth regulators on growth and productivity of bean plants (phaseolus vulgaris l.). Res.j. agr. and Biological sci.,3(5):440-446.

Gharib, A.A., shahen, M.M. and Ragab A.A. 2009. Influence of rhizobium inoculation combined with azotobacterchrococcum and bacillus megaterium var phosphaticum on growth, nodulation, yield and quality of two snap bean (Phasealus vulgaris, L.)Cultivers. 4 th
Conference on Recent Technologies in Agriculture: 650-660.

Gupta, U.C., Jame, Y.W., Campbell, C.A., Leyshon, A.J. and Nicholaichuk, W. 1985. Boron toxicity and deficiency: a review. Can. J. Soil Sci., 65: 381-409.

Jackson, M.L. 1973. Soil Chemical Analysis. Prentice Hall of India Pvt. Ltd., New Delhi, 498.

Keneni, A., Assefa, F. and Prabu, P.C. 2010. Isolation of phosphate solubilizing bacteria from the rhizosphere of faba bean of Ethiopia and their abilities on solubilizing insoluble phosphates. $J$ AgricSci Technol. 12: 79-89.

Massoud, O.N. , Ebtsam, M., Morsy and Nadia, H. E. 2009. Field response of snap bean (Phaseolus vulgaris L.) to N2-fixers bacillus circulans and arbuscularmycorrhizal fungi inoculation through accelerating rock phosphate and feldspar weathering. Australian j. of Basic and Applied Sci., 3(2): 844-852.

Meseret, T. and Amin, M. 2014. Effect of different phosphorus fertilizer rates on growth, dry matter yield and yield components of common bean (Phaseolus vulgaris L.). world j. agric.,res.,2(3):88-92 .

Mgnetski, K.P., Tsugarov, Y.A. and Malkov, B.K. 1959. New method for plantand soil analysis. Agricultural Academy press ManometricTechniques.U.M.P., Bell Burris Stauffer. (C.f. Khalil, M.A.I. ph.D. thesis, Fac.Agric., Zagazig Univ., 1982) .

Niab. 2002. Sixth five yearly report of Nuclear Institute for Agriculture and Biology, Faisalabad, Pakistan. pp. 46-47.

Njira, K. O. and Nabwami, J. 2015. A review of effects of nutrient elements on crop quality. African Journal of Food, Agriculture, Nutrition and Development, 15 (1): 9777-9793.

Pregl, E. 1945. Quantitative organic micro analysis. 4th Ed. J. Chundril, London.Rain Fed Agriculture, pp: 13-17. Central Institute for Dry Land.

Rodríguez, H. and Fraga, R. 1999 . Phosphate solubilizing bacteria and their role in plant growth promotion. Biotech Adv. 17: 319-339.

Sabry, M. Y., Gamal, S. R. and Salama, A. A. 2017. Effect of phosphorus sources and arbuscularmycorrhizal inoculation on growth and productivity of snap bean (Phaseolus vulgaris L.). GesundePflanzen . 69:139-148.

Salem, M.F. and Sally, A. M. 2012. The potential coinoculation of biofertilizers and biopesticide in organic production of snap bean under the conditions of newly reclaimed land in Egypt. Australian Journal of Basic and Applied Sciences, 6(8): 635-644, ISSN 1991-8178.

Schachtman, D. P., Reid, R. J. and Ayling, S. M. 1998. Phosphorus uptake by plants: from soil to cell. Plant Physiol. 116 44745310.1104/pp.116.2.447. 
Snedecor, G. M. and W. G. Cochran. 1991. Statistical methods, Sixth Edition Iowa State Univ. Press, Amer. Iowa, USA.

Taiz, L., Zeiger, E., Møller, I.M. and Murphy, A. 2015. Plant Physiology and development, Sixth Edition. Sinauer Associates, Inc.
Watanabe, F.S., Olsen, S.R. (1965). Test of an ascorbic acid method for determining phosphorus in water and $\mathrm{NaHCO} 3$ extracts from soil. Soil Science Society of America Proceeding, 29, 677678.

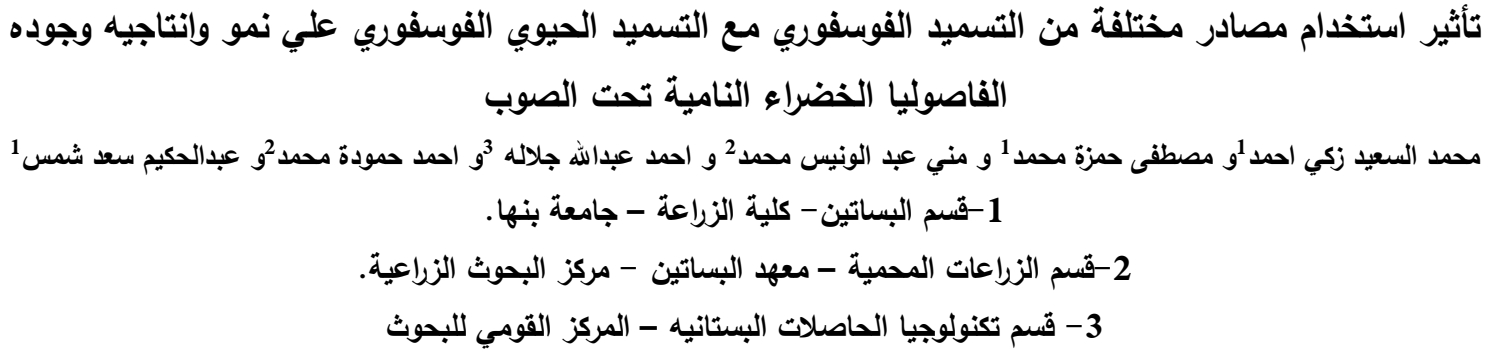

اجريت تجربة حقلية خلال الموسم النيلي لعامي 2017-2018 و 2018- 2019 في مزرعة خاصه بقريه دملو - محافظه القليوبية.

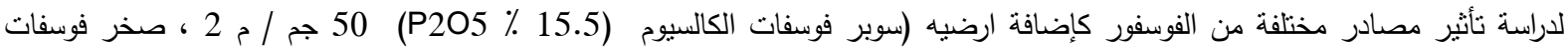

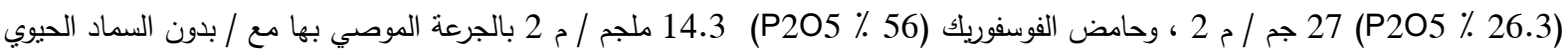
فوسفاتين • "تحتوي علي بكتيريا مذيبه للفوسفور" وكذللك التفاعل بينهما على النمو الخضري والتركيب الكيميائي والإنتاجية وكذلك جودة القرنة من

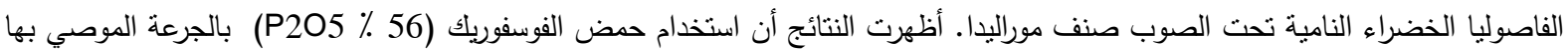
من الأسدة المعدنية الفوسفاتية اعطت أعلى القيم بشكل ملحوظ في جميع جوانب النمو الخضري المقاسة ، والمكونات الكيميائية للنمو الخضري ،

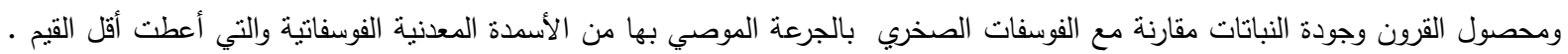
بالإضافة إلى ذلك ، فإن إخصاب نباتات الفاصوليا الخضراء بأسمدة الفوسفور الحيوي والذي يحتوي على بلى بكتيريا مذيبه للفوسفور بمعدل 4 لترات

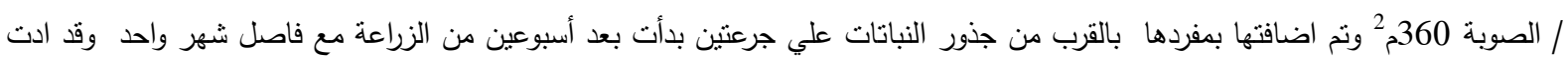

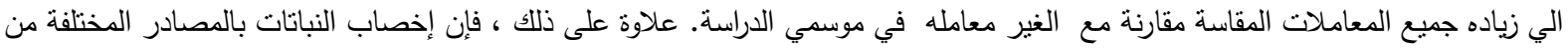

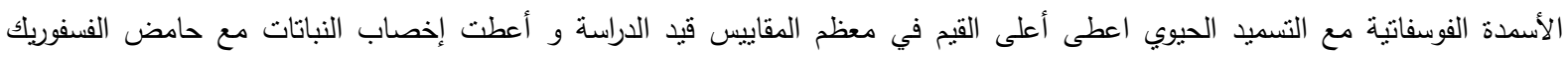
بالإضافة إلي السماد الحيوي أعلى القيم في جميع جوانب النمو الخضري ، وإنتاجية القرون الخضراء وأفضل جودة مقارنة مع المعاملات الأخرى خلال موسمي الدراسة.

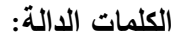
الفاصوليا الخضراء- سوبر فوسفات الكالسيوم - صخر الفوسفات - حمض الفوسفوريك- فوسفاتين - البكتيريا المذيبة للفوسفور - التسميد الحيوي - النمو الخضري- المحصول الثمري- جودة الثمار - الصوبة البلاسنيكية 